\title{
Aspects of the reproductive biology of Zingiber spectabile (Zingiberaceae) ${ }^{1}$
}

\author{
Kamilla Ferreira Rezende², Robson dos Santos Alves da Silva², Patrícia Campos da Silva², \\ Maria Helena Menezes Cordeiro ${ }^{2 *} \mathbb{D}$, Celice Alexandre Silva ${ }^{2}$
}

$10.1590 / 0034-737 X 202168020002$

\begin{abstract}
Ginger (Zingiber spectabile) is cultivated worldwide as a floriculture and landscaping species. Studies on the biology and floral morphology of this species are important for its improvement; however, they are scarce. We investigated the reproductive biology and floral morphology of gingers grown in a germplasm bank. Floral development was monitored during the pre-anthesis and anthesis periods. Floral morphometry, pollen viability, stigmatic receptivity, volume and concentration of nectar sugar, and performance of possible pollinators were evaluated. Ginger flowers had a 24-h durability. Ginger torch is an allogamous species that exhibits floral hercogamy like other Zingiberaceae. Ginger flowers had a 12-h anthesis. During anthesis, floral structures related to reproduction such as the style, stigma, and anther crest continued to develop, increasing floral herkogamy. Pollen viability was above $70 \%$ and the stigma remained receptive throughout the anthesis period. Hummingbirds were the only pollinators recorded in the study area that were able to move the anther crest. Fruiting was determined in a natural pollination system. The occurrence of nocturnal anthesis characterized by an increase in the development of reproductive structures and nectar production suggests that the species is adapted to nocturnal visitors.
\end{abstract}

Keywords: anther crest; ginger; hummingbird; pollination; invasive species.

\section{INTRODUCTION}

Zingiber Boehm. is a large genus of the Zingiberaceae family comprising approximately $80-150$ species (Wu \& Larsen, 2000). Sabu \& Skinner (2004) described approximately 25 Zingiber spp. of medicinal, aromatic, gustatory, and ornamental importance. In Brazil, ginger (Zingiber officinale) and shampoo ginger (Zingiber zerumbet) are the two species most extensively cultivated (Maas \& Maas, 2015).

Zingiberaceae inflorescences have firm and colorful bracts, bisexual flowers, and zygomorphs with large or very small lateral staminodes, which usually have a stamen, an anther with two teaks, a filiform stylus stuck between the teaks, an infundibuliform stigma, and a lower ovary; their fruits are capsule-shaped and can be of the fleshy type, with a longitudinal and dehiscent persistent calyx (Kamer \& Maas, 2003; Costa et al., 2011).

The floral morphology of Zingiberaceae is considered innovative, consisting of specialized structures such as the anther crest, which is equipped with an appendix that extends from the top of the anther; this crest is considered to be extremely rare compared to those of other angiosperm flowers (Fan \& Li, 2016).

The reproductive apparatus of Zingiberaceae evolved from the plant-pollinator interaction, with a significant correlation being observed between floral morphology and pollination guilds. The floral visitors and pollinators that have been reported for species of this family are small bees of the genus Amegilla, hummingbirds, and spiderhunters (Nectariniidae) (Sakai et al., 2013). However,

\footnotetext{
Submitted on July $14^{\text {th }}, 2020$ and accepted on November $4^{\text {th }}, 2020$

${ }^{1}$ This work belongs to the Undergraduate thesis of the first author.

${ }^{2}$ Universidade do Estado de Mato Grosso, Laboratório de Botânica, Tangará da Serra, Mato Grosso, Brazil. kamilla.fr4@gmail.com; robson.silva1@unemat.br; campos_bio@ yahoo.com.br; helenaagromc@gmail.com; celice@unemat.br

*Corresponding author: helenaagromc@gmail.com
} 
ginger is considered to be a sterile species, with gametophytic self-incompatibility (Dhamayanthi et al., 2003).

Knowledge of the reproductive system and the mechanisms involved in species pollination is important in specifying the breeding methods to be applied and the methodologies used to obtain new hybrids. Despite its commercial importance, studies on the reproductive morphology and biology of ginger are scarce. In addition, phenology and floral biology information is important for species conservation and commercial cultivation (Bernardello et al., 2001; Palupi et al., 2019).

Ginger (Zingiber spectabile Griff.) originates from Malaysia and is cultivated as an ornamental plant owing to the beauty of its inflorescence, while it is also used in oriental cuisine for the preparation of exotic dishes and extracts (Aguiar et al., 2014). This species is popularly known as ice cream, ornamental ginger, maraca, or shampoo. In Brazil, it is cultivated as part of an expansive range of ornamental flowers, mainly owing to some characteristics that favor its production, such as the country's climatic conditions as well as land, labor, and water availability (Junqueira \& Peetz, 2008).

In this respect, the aim of this study was to provide an in-depth analysis of the reproductive biology of ginger (Zingiber spectabile) by describing its morphology, floral biology, and pollination system in order to provide a foundation for future studies on the genetic improvement of the species.

\section{MATERIAL AND METHODS}

\section{Study area}

The study was carried out from March to November 2018 and 2019 at the Germplasm Bank of Tropical Plants, State University of Mato Grosso, Brazil (14 39'22" N and $57^{\circ} 25^{\prime} 32^{\prime \prime} \mathrm{W} ; 321 \mathrm{~m}$ altitude).

The study site has a tropical climate, with a dry season from May to September and a rainy season from October to April, an average annual rainfall of $1,830.8 \mathrm{~mm}$, an average temperature of $24{ }^{\circ} \mathrm{C}$, and a relative humidity of $70-80 \%$ (Dallacort et al., 2011). The soil of the region is dystrophic red latosolo with a clay texture, while the original vegetation of the region is fragmented due to soybean and corn monocultures.

\section{Floral biology of Zingiber spectabile}

The floral biology study involved the analysis of flowers from five inflorescences in the pre-anthesis $(\mathrm{N}=$ 30) and anthesis $(\mathrm{N}=30)$ stages.

Pre-anthesis, anthesis, anther dehiscence, stigmatic receptivity, and possible movement of floral structures, such as the anther crest, were observed. Floral senescence was characterized by the darkening of floral structures, loss of luster, abscission of flowers, and loss of stigmatic receptivity.

\section{Floral morphology and morphometry}

The morphological characteristics of the inflorescence and the external and internal structures of the flowers were detailed and represented by means of illustrations.

The size of the fully developed inflorescence $(\mathrm{N}=10$ inflorescences), the number of bracts formed by each inflorescence $(\mathrm{N}=5)$, and the number of flowers produced by inflorescences $(\mathrm{N}=5)$ were evaluated.

Floral morphometry was performed on 35 flowers, which were collected from seven individuals and 14 inflorescences. The collection sessions were carried out in six stages, starting at 8:00 a.m. and ending at 8:00 p.m., with 2-h intervals between them.

Fully developed flowers were used and stored in flasks containing $70 \%$ alcohol. The height of the following structures was measured in the collected flowers using a stereomicroscope and graph paper (Schvinn et al., 2014): bracteoles, calyx, corolla, lateral petals, anther crest, pistil and stigma, anther, nectariferous glands, and ovary. The mean and standard deviation of each floral structure measurement were determined for each hour analyzed.

\section{Pollen viability and stigmatic receptivity}

Pollen viability was determined in 35 flowers of different inflorescences in the pre-anthesis and anthesis stages, which were stored in flasks containing a mixture of $70 \%$ alcohol and acetic acid solutions.

The collection sessions were carried out in seven stages from 8:00 a.m. to 8:00 p.m., with 2-h intervals between them. Five slides containing pollen grains from the samples obtained at each collection time were stained with 3\% acetic carmine (Kearns \& Inouye, 1993) and up to 200 grains per slide were counted.

Stigmatic receptivity was evaluated in 35 stigmas of fresh flowers at seven time points, starting at 8:00 a.m. and ending at 8:00 p.m., with 2-h intervals between them. Stigmatic receptivity was determined by the reaction of $3 \%$ hydrogen peroxide and the release of $\mathrm{O}_{2}$ bubbles owing to the presence of the peroxidase enzyme found in the stigmas.

\section{Nectar volume and sugar concentration}

Nectar volume and sugar concentration were determined in fresh flowers, formed in the basal $(\mathrm{N}=35$ flowers) and apical ( $\mathrm{N}=35$ flowers) regions of 15 different ginger inflorescences. The flowers formed on the lower half of the inflorescence were characterized as basal, while those formed on the upper half of the same inflorescence were characterized as apical. The nectar volume and sugar concentration were assessed at seven time points from 
8:00 a.m. to 8:00 p.m., with 2-h intervals between assessments. At each time point, the average volume of nectar produced was analyzed using a graduated micropipette $(0.5 \mu \mathrm{L}$ to $10 \mu \mathrm{L})$. The sugar concentration was measured with the aid of a pocket refractometer PALBX/RI (Brix 0,0-93,0\%) and resolution 0,0001.

\section{Pollinator observation}

Field observations were performed for five days during the peak flowering period of 2019 for the evaluation of possible floral visitors and pollinators. Observations were undertaken at alternate times, in the morning and afternoon, on flowers of 25 different inflorescences, for a total of $30 \mathrm{~h}$ of observation.

The visit time and duration as well as the behavior of the visitor and the collected resource were analyzed during the observations. The floral visitors observed were photographed and identified by an expert. The pollinators were classified as legitimate when they visited the flower and made contact with the stigma and the anthers (Linhart, 1973). After the pollinator visits, the flowers were analyzed in terms of anther crest displacement.

Complementary evaluations of diurnal and nocturnal floral visitors were carried out with the aid of three camera traps placed in the Germplasm Bank next to the ginger inflorescences. The equipment was kept in operation for $24 \mathrm{~h} /$ day during the peak flowering period from March 10$19,2020$.

\section{Reproductive system}

The self-pollinating ability of flowers was evaluated in $2019(\mathrm{~N}=5$ inflorescences $)$ and $2020(\mathrm{~N}=7$ inflorescences) by the formation of fruit via spontaneous self-pollination, and the inflorescences were bagged when young and kept bagged until senescence. We compared the number of fruits per inflorescence and the number of seeds per fruit, with the inflorescences being simply marked (open pollination) and made available to pollinators $(\mathrm{N}=5)$ in 2019 and $(\mathrm{N}=10)$ in 2020.

\section{RESULTS}

\section{Floral biology}

In the study area, the first ginger inflorescences appeared at the beginning of the rainy season (September 2018) and the first flowers appeared one month after inflorescence emission. The flowering peak occurred in February and March 2019. The flowers appeared from the bottom to the top of the inflorescences and the number of flowers opened per day/inflorescence was approximately 2-3. Fruiting occurred in February and March of the same year.

Pre-anthesis started at 06:00 a.m. and ended at 08:00 a.m. of the same day; during this stage, the sepals and petals closed, but the teaks were semi-open and the stigma was receptive. The beginning of anthesis was observed from 10:00 a.m. and, during the observation period, the calyces and corollas of most flowers were fully open, while their anthers had dehiscent teaks and receptive stigmas.

The duration of anthesis was $12 \mathrm{~h}$. The floral structures most exposed and associated with pollinator attraction, such as the sepals, petals, and lips, continued to develop throughout almost the entire anthesis stage (Table 1). The anther showed no teak development during the period when the flower remained open, whereas the stigma and style continued to develop until 12:00 p.m. (Table 1). The anther crest reached its maximum development $(1.82 \mathrm{~cm})$ at 2:00 p.m. (Table 1) and the nectariferous glands exhibited variable sizes during the anthesis stage $(0.14-1.12 \mathrm{~cm})$ (Table 1).

Senescence was characterized by loss of brightness, withering, and closing of the petals and sepals. Senescence started at 11:00 p.m. and lasted 7 h. Flower abscission occurred about $24 \mathrm{~h}$ after pre-anthesis. During this process, the calyx and corolla fell, and the ovary remained inside the bracts of the inflorescence. The anther crest showed no spontaneous movement but did move during the visit of some floral visitors in order to facilitate access to the nectar.

\section{Floral morphology and morphometry}

Ginger inflorescences were cylindrical with a rounded apex and oval, outwardly curved bracts of fleshy consistency (Fig. 1a). During the aging process, the color of the inflorescences changed from light yellow to orange red. The inflorescences were long $(18.88 \pm 2.66 \mathrm{~cm}$ on average), consisted of $127.2 \pm 2.63$ bracts, and contained, on average, approximately $118 \pm 18$ flowers per inflorescence.

Ginger flowers were zygomorphic, hermaphroditic (Figs. 1b, c, d), and consisted of two cream-colored curved bracteoles. One of the bracteoles was located on the exterior of the flower; the other was located in the interior of the flower and was smaller and of finer consistency than the exterior bracteole (Figs. 1e-f). The calyx consisted of three cream-colored sepals; the first curved sepal was located at the top of the crest (Fig. 1g) and the second and third were fused and located at the bottom of the corolla (Fig. 1h). The corolla was formed by three fused petals and two side petals of the same size and was concave and pitted. The lip was constructed by the fusion of lateral staminodes that appeared as lobes at the base of the lip and were purple colored with yellow spots (Fig. 1i).

The anther was sessile, with two teaks that opened longitudinally. The anther crest was positioned above the stigma (Fig. 1j). The pistil was long and the stylus passed between the teaks of the stamen (Fig. 1j). The stigma had 
a globose shape and a cream-colored ciliate and was positioned above the anther (Fig. 1j). The inferior ovary had two nectariferous glands located at the base (Fig. 1k) and was trilocular, multiovular, with axile placentation (Fig. 11). When ripe, the seeds were black and covered with a white aryl with lobed edges.

\section{Pollen viability and stigmatic receptivity}

The pollen viability that resulted from all analyses was above $71.0 \%$ (Fig. 2). The period during which the greatest pollen viability was detected $(80.2 \%)$ was $12: 00$ a.m. The stigma was receptive at all time points analyzed (Fig. 2).

\section{Nectar volume and sugar concentration}

The production of nectar in gingers continued during anthesis, from 10:00 a.m. to 8:00 p.m., in the flowers of the base and apex of the inflorescence (Fig. 3). The average volume of nectar measured in flowers at the base and apex of the inflorescence during anthesis was $2.0 \pm 1.9 \mu \mathrm{L}$ and $0.8 \pm 0.4 \mu \mathrm{L}$, respectively (Fig. 3). The peak of nectar production by the base flowers $(5.0 \mu \mathrm{L})$ was reached at 8:00 p.m. (Fig. 3) and was four times greater than the peak nectar volume produced by the apex flowers $(1.2 \mu \mathrm{L})$ (Fig. $3)$. The highest sugar concentration in the nectar was 25.5 ${ }^{\circ}$ Brix, determined at 6:00 p.m.

\section{Pollinator observation}

The presence of the planalto hermit (Phaethornis pretrei) and fork-tailed woodnymph (Thalurania furcata) hummingbirds was recorded during the observations in the study area (Fig. 4a). The birds visited most frequently in the morning and early afternoon, with each visit lasting on average $15 \mathrm{~s}$ and being carried out randomly between different individuals or on flowers of the same inflorescence located at the base or apex.

After the visits, we observed whether the crest had been manipulated by the visitor by being displaced laterally (Fig. 4b) during foraging. Ants, bees, beetles such as ladybugs, and hemiptera such as spittlebugs were detected among the bracts, but no displacement of the anther crest was observed because of the presence of these visitors.

The camera traps did not record any nocturnal pollinators during the observation period.

\section{Reproductive system}

No fruit formation resulted from spontaneous selfpollination experiments in 2019 and 2020. The ginger fruits that formed from February to March 2019 and 2020 were the results of natural pollination. Fruit formation was recorded only in the basal bracts of the inflorescence. In 2019 , an average of $6.0 \pm 3.2$ fruit/inflorescence $(\mathrm{N}=20)$ was recorded. The number of seeds/fruit varied from 2 to

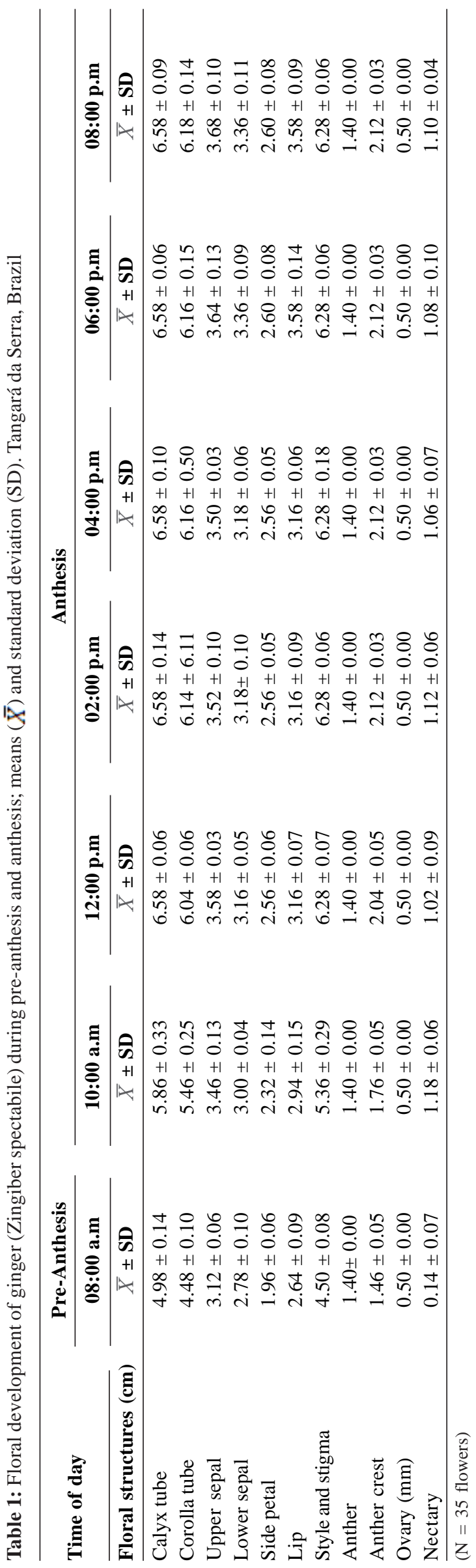

Rev. Ceres, Viçosa, v. 68, n.2, p. 096-104, mar/apr, 2021 
$34(\mathrm{~N}=20)$. In 2020, the number of fruit formed/ inflorescence was $2.3 \pm 7.0(\mathrm{~N}=10)$ and the number of seeds/fruit ranged from 4.5 to $20(\mathrm{~N}=10)$. The fruit adhered to the inflorescence, had an ellipsoid shape, was about 3 $\mathrm{cm}$ high and $1 \mathrm{~cm}$ long, and had three loci.

\section{DISCUSSION}

The appearance of ginger flower stems from underground rhizomes at the beginning of the rainy season was similar to that observed in other Zingiberaceae species, which intensify their development with the heat progression during the summer and the constant rains (Parthasarathy et al., 2012; Palupi et al., 2019). The absence of flowering during cooler and drier periods of the year, as seen in the study area, may be attributed to a possible reduction in the species' metabolism, thereby reducing the energy cost for growth and flowering.

The calyx and corolla developed during part of the anthesis period and their sizes were similar to those of flowers of other species, such as Z. tenuifolium and $Z$. ottensii (By et al., 2015; Huong et al., 2016).

Among the floral structures, the anther crest stood out as an anther attachment or appendix, as has also been described in other studies (Chaveerach et al., 2007; Huong et al., 2016; Nurainas \& Arbain, 2017; Palupi et al., 2019), and is considered to be an important structure for the protection of the stigma. The ginger anther crest was longer compared to those of other species such as $Z$. ottensii and Z. tenuifolium (By et al., 2015; Huong et al., 2016); additionally, it was less developed than those of $Z$.

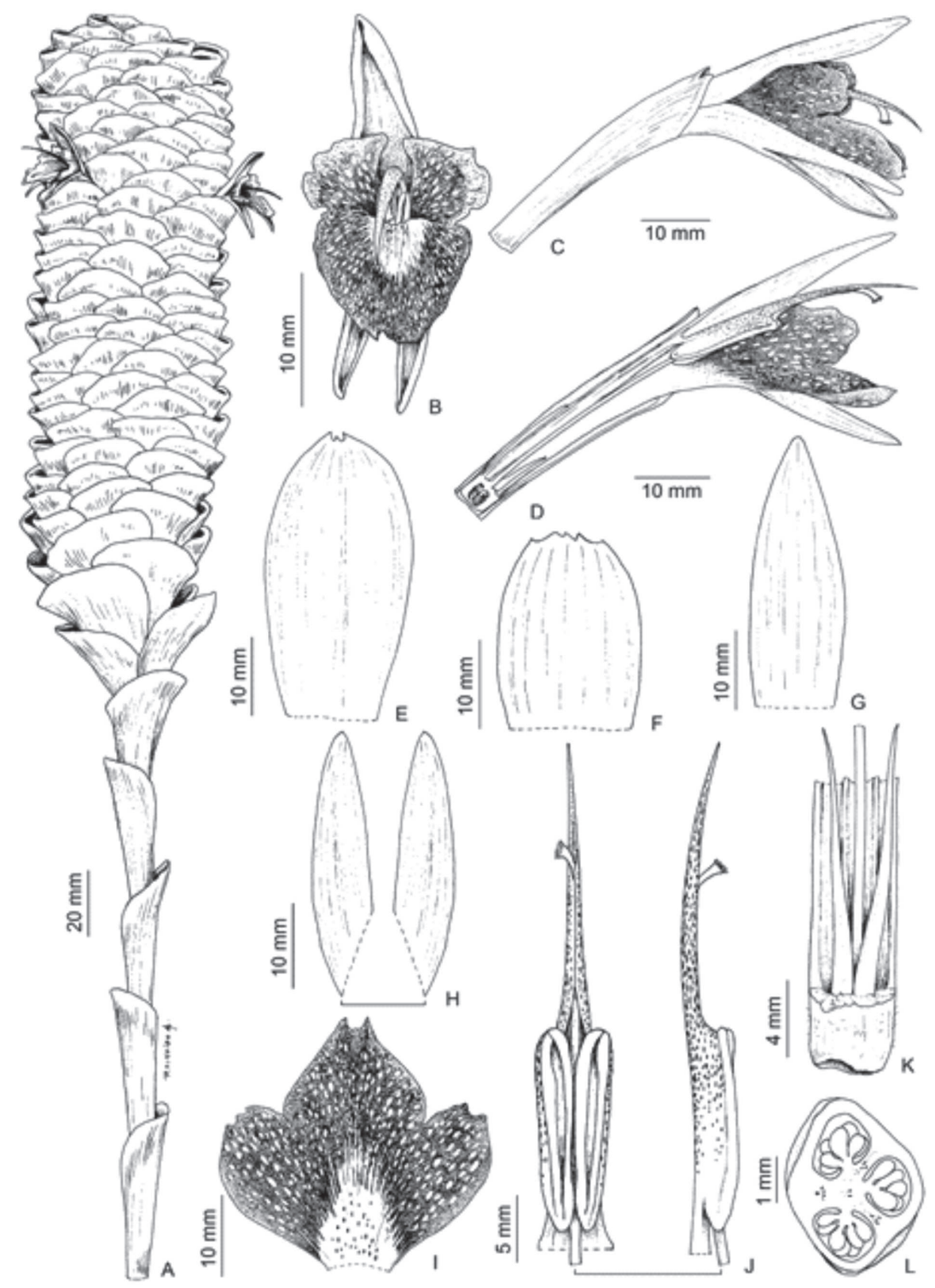

Figure 1: A) terminal ginger (Zingiber spectabile) inflorescence, B) front view of the ginger flower, C) side view of the flower, D) side view with details of the internal structures, E) detail of the first bracteole, F) detail of the second bracteole, G) sepal located above the corolla, H) detail of the two fused sepals, I) details of the corolla, J) frontal and lateral view of the details of the anther, crest, and stigma insertion, K) infertile ovary with two nectar glands at the base, L) details of the trilocular ovary. Tangará da Serra, Brazil. 
phumiangense and Z. alba (Chaveerach et al., 2007; Nurainas \& Arbain, 2017).

Fan \& Li (2016) highlighted that more than 25 Zingiberaceae genera have this innovative floral structure. The different genera vary greatly in terms of shapes and sizes, while they have morphological similarities to Costaceae flowers.

Similar to the data reported by Palupi et al. (2019) for Zingiber spectabile in Indonesia, the period of increased pollen viability was 12:00 p.m. Stigmatic secretion was not observed in our study in Brazil.

The volume and concentration of sugars in ginger nectar, as well as the coloration patterns of the inflorescences ranging from light yellow to red, were compatible with those reported by Freitas \& Sazima (2001) for Ornithophilous species.

The pattern of nectar production by flowers located between the base and the apex of the inflorescence was

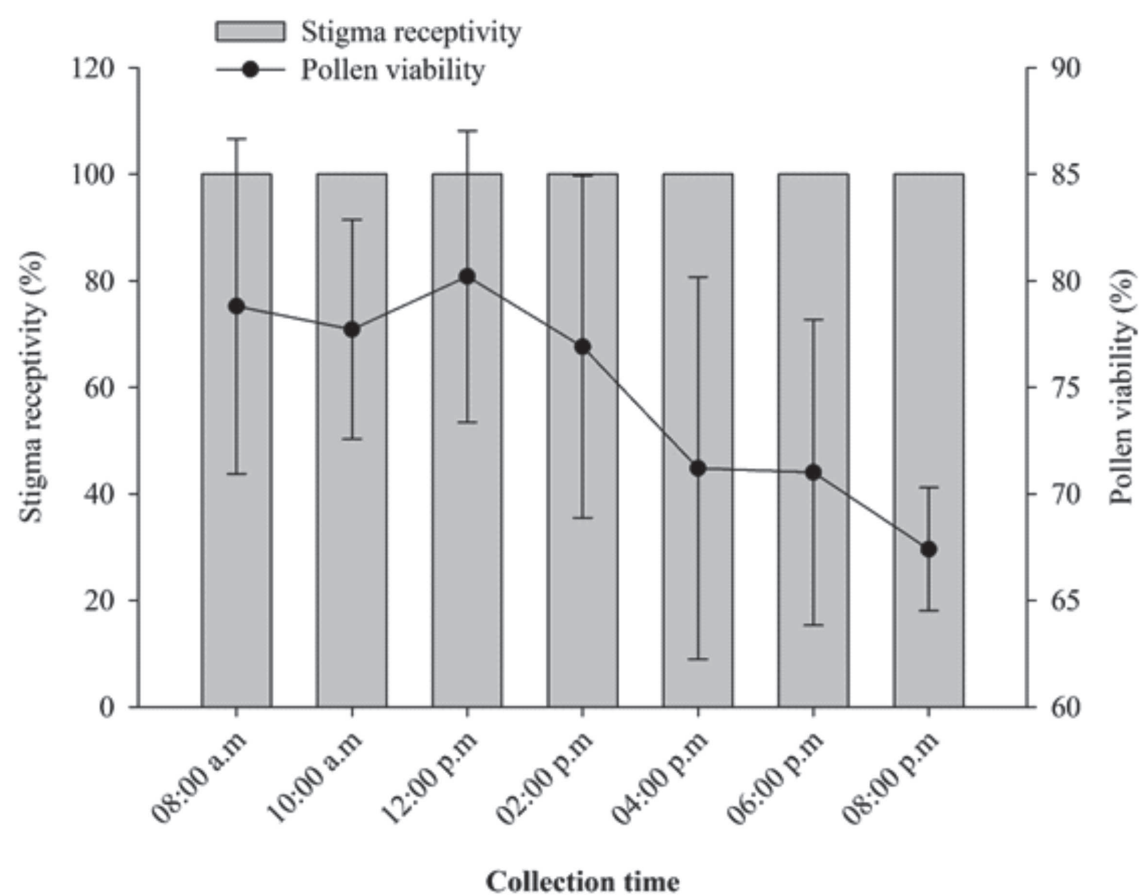

Figure 2: Pollen viability and stigmatic receptivity in ginger (Zingiber spectabile) flowers. Tangará da Serra, Brazil.

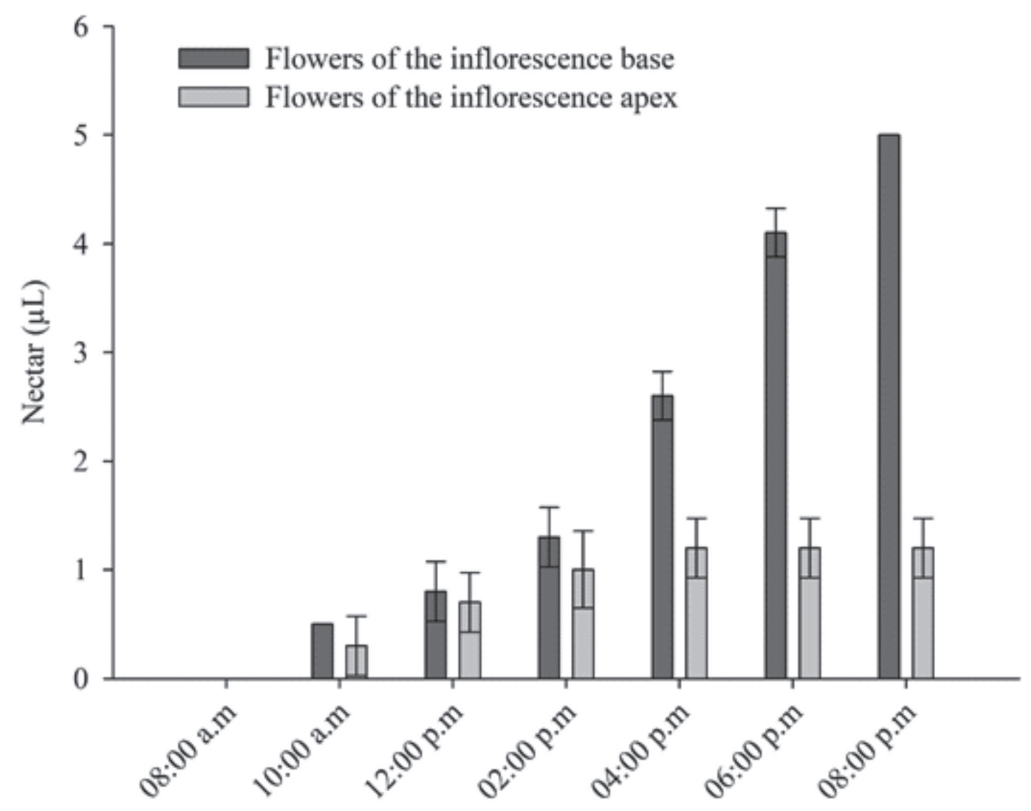

Collection time

Figure 3: Nectar availability in flowers at the base and apex of ginger (Zingiber spectabile) inflorescences. Tangará da Serra, Brazil. 
asymmetric throughout the anthesis period. Ginger inflorescences remained in bloom for approximately $2-3$ months, thus being important long-term sources of nectar (daily average of $0.5-5 \mu \mathrm{L}$ for base flowers and $0.3-1.2 \mu \mathrm{L}$ for apex flowers). During the inflorescence peak, each ginger flower lasted only a single day. With the inflorescence aging and taking into account the estimated daily energy expenditure by hummingbirds and other nectarine pollinators, these flowers may not stimulate an attractive pattern of visits by some pollinators, especially at the inflorescence peak.

Although the absence of nocturnal activity was confirmed, it is possible to conclude that ginger flowers are adapted to nocturnal visitors owing to three factors: (1) anthesis was maintained throughout the night, (2) nectar production increased in the late afternoon and evening, and (3) the corolla developed the most during this period. Therefore, we can suggest that nocturnal ginger pollinators, if present in the study area, would be more efficient than diurnal pollinators.

Many plants with specialized floral traits are often visited by various pollinator types and, in some cases, the primary pollinators predicted by pollination syndromes play only a minor role in reproductive success (Rivera-Marchand \& Ackerman, 2006). The patterns of production of floral rewards, such as nectar, may correspond to the period of activity of the main pollinators (Heinrich, 1975). The nectar characteristics (e.g., standard secretion and sugar composition) of species that have both nocturnal and diurnal pollinators should be congruent with the requirements of both pollinator groups, if both groups of visitors act as effective pollinators (Amorim et al., 2013).

The manipulation of the ginger anther crest during the visits by the planalto hermit and fork-tailed woodnymph hummingbirds was considered to be proof of a visit to the flower by these pollinators. The manipulation of the anther crest by bees was registered in Z. densissimum, favoring the deposition of pollen on the head or other parts of the bee's body (Fan \& Li, 2016). Birds, hymenopterans such as bees, lepidopterans, and hummingbirds are registered pollinators of other Zingiberaceae species such as the torch ginger (Etlingera elatior), Euglossine bees (Alpinia glabra), and Z. longipedunculatum (Sakai et al., 1999; Specht et al., 2001).

The expansion of hercogamy during floral anthesis impairs the spontaneous self-pollination of ginger. In addition, fruit formation that only takes place in the basal bracts of the inflorescence suggests that the asymmetric distribution of nectar in the basal and apical flowers may interfere with the visitation pattern.

Some Zingiberaceae species rarely produce fruit, a fact probably indicating incompatibility with or absence of pollinators in the area (Choon et al., 2016; Thomas et al., 2016). The low fruit production via natural pollination reinforces the hypothesis that asexual reproduction is the main form of ginger propagation. Studies have concluded that ginger is possibly a sterile hybrid that originated from the cross of two distant species and has the ability to survive owing to a successful strategy, such as vegetative propagation (Peter et al., 2007). However, Palupi et al. (2019) recorded fruiting in manual self-pollination and cross-pollination tests in Indonesia.

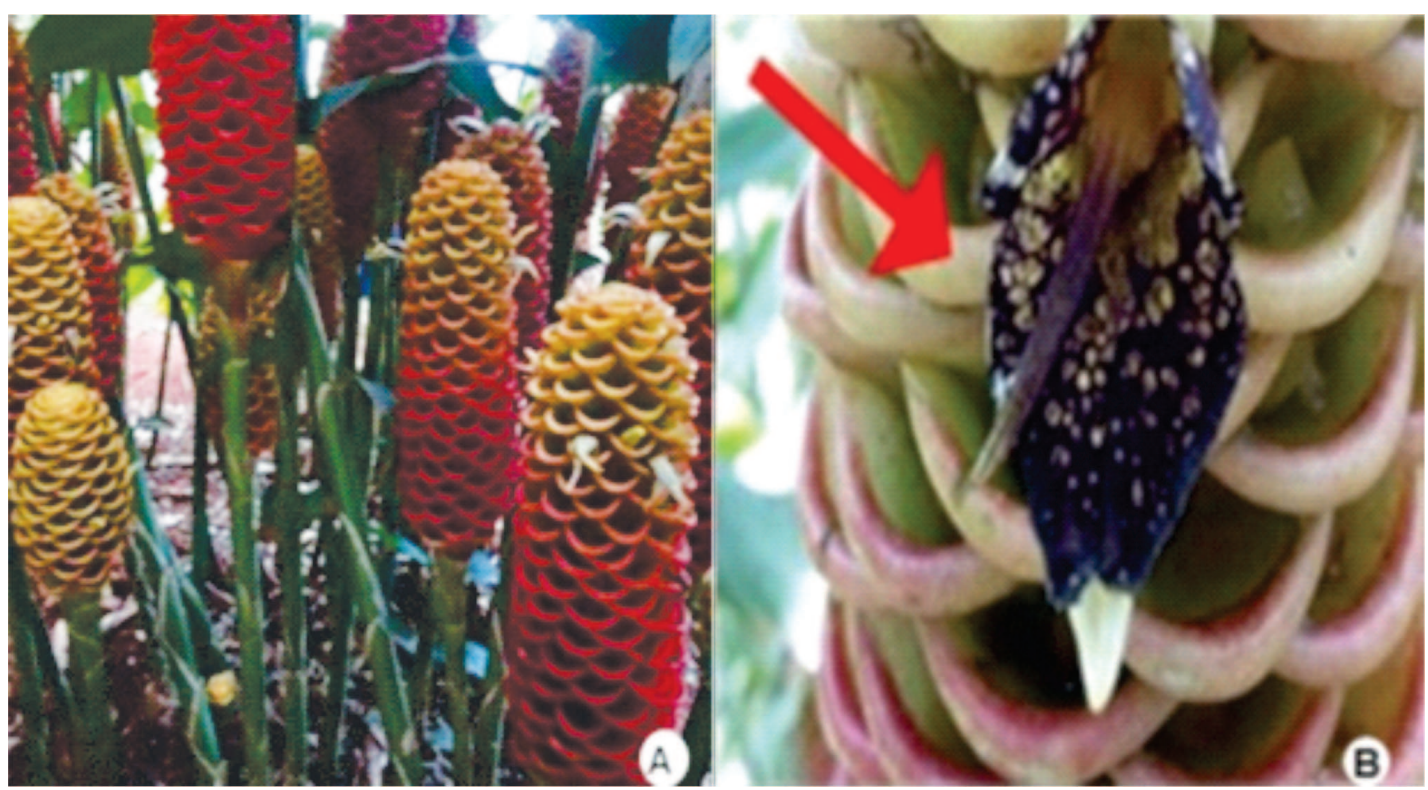

Figure 4: (A) Inflorescences and (B) displacement of the anther crest (arrow) in ginger (Zingiber spectabile) flowers. Tangará da Serra, Brazil.

Rev. Ceres, Viçosa, v. 68, n.2, p. 096-104, mar/apr, 2021 
The successful establishment of introduced species and their ability to attract resident pollinator services are fundamental in understanding the role of pollination ecology during the phase of establishment of exotic plants (Memmott \& Waser, 2002). The establishment of introduced plants probably depends on many factors, such as their reproduction system, their similarity to native plants present in the introduction area, their abundance, and the time that elapsed since their introduction (Thompson \& Knight, 2018).

Knowledge of these integrations can contribute to the design of future studies on plant breeding programs, while knowledge of the pollinator community behavior can facilitate the understanding of factors that determine the reproductive success of introduced plant species.

\section{CONCLUSIONS}

The production of nectar by the flowers located between the base and the apex of the inflorescence was asymmetrical and there was an increase in nectar production in the late afternoon and evening. The planalto hermit and fork-tailed woodnymph hummingbirds were the only pollinators recorded in the study area that were able to move the anther crest. The expansion of hercogamy during floral anthesis made spontaneous self-pollination difficult, and the low fruit formation, detected only in natural pollination treatments, indicated that asexual reproduction is the main form of propagation for this species.

\section{ACKNOWLEDGEMENTS, FINANCIAL SUPPORT AND FULL DISCLOSURE}

This research was supported by a grant from the Research Support Foundation of Mato Grosso State (FAPEMAT, process 159855/2014) and Council of Technological and Scientific Development (CNPq, process 306183/2018). Financed in part by the Coordination for the Improvement of Higher Education Personnel - Brasil (CAPES).

The authors declare that there were no conflicts of interest in carrying out or publishing this work.

\section{REFERENCES}

Aguiar ATE, Gonçalves C, Paterniani MEAGZ, Tucci MLS \& Castro CEF (2014) Instruções agrícolas para as principais culturas econômicas. Campinas, IAC. 460p. (Technical Bulletin, 200).

Amorim FW, Galetto L \& Sazima M (2013) Além da síndrome da polinização: ecologia do néctar e o papel dos polinizadores diurnos e noturnos no sucesso reprodutivo de Inga sessilis (Fabaceae). Plant Biology, 15:317-327.

Bernardello G, Anderson GJ, Stuessy TF \& Crawford DJ (2001) A survey of floral traits, breeding systems, floral visitors, and pollination systems of the angiosperms of the Juan Fernández islands (Chile). The Botanical Review, 67:255-308.
By L, Xia N \& Skornickova J (2015) Taxonomic studies on Zingiber (Zingiberaceae) in China II: Zingiber tenuifolium, a new species from Yunnan. Phytotaxa, 227:92-98.

Costa FRC, Espinelli FP \& Figueiredo FOG (2011) Guia de Zingiberales dos Sítios PPBio na Amazônia Ocidental Brasileira. $1^{\text {st }}$ ed. Manaus, Áttema, 280p.

Chaveerach A, Mokkamul P, Sudmoon R \& Tanee TA (2007) New species of Zingiber (Zingiberaceae) from Northern Thailand. Taiwania, 52:159-163.

Choon SY, Ding P, Mahmud TMM \& Shaari K (2016) Phenological growth stages of torch ginger (Etlingera elatior) inflorescence. Pertanika Journal of Tropical Agricultural Science, 39:73--78

Dallacort R, Martins JA, Inoue MH, Freitas PSL \& Collete AJ (2011) Distribuição das chuvas do município de Tangará da Serra, médio norte do estado de Mato Grosso, Brasil. Acta Scientiarum. Agronomy, 33:193-200.

Dhamayanthi KPM, Sasikumar B \& Remashree AB (2003) Reproductive biology and incompatibility studies in ginger (Zingiber officinale Rosc). Phytomorphology, 32:123-131.

Fan Y \& Li Q (2016) Tail-like anther crest aids pollination by manipulating pollinator's behaviour in a wild ginger. Scientific Reports, 6:1-6

Freitas L \& Sazima M (2001) Nectar features in Esterhazya macrodonta, a hummingbird-pollinated Scrophulariaceae in southeastern Brazil. International Journal of Plant Research, 114:187-191.

Heinrich B (1975) Bee flowers: A hypothesis on flower variety and blooming times. Evolution, 29:325-334.

Huong L, Truong V \& Ly N (2016) Zingiber ottensii Valeton (Zingiberaceae) - a newly recorded species for Vietnam. Bioscience Discovery, 7:93-96.

Junqueira AH \& Peetz MS (2008) Mercado interno para os produtos da floricultura brasileira: características, tendências e importância socioeconômica recente. Ornamental Horticulture, $14: 37-52$

Kamer MH \& Maas PJM (2003) Zingiberaceae. Available at: http:/ /botanica.sp.gov.br/files/ 2016/ 02/Zingiberaceae.pdf. Accessed on: May $31^{\text {th }}, 2019$.

Kearns CA \& Inouye DW (1993) Techinques for pollination biologists. $1^{\text {st }}$ ed. Niwot, University Press of Colorado. 586p.

Linhart Y (1973) Ecological and behavioral determinats off pollen dispersal in hummingbird pollinated Heliconia. The American Naturalist, 107:51-523.

Maas P \& Maas H (2015) Growing knowledge: an overview of seed plant diversity in Brazil. Rodriguésia, 66:1085-1113.

Memmott J \& Waser NM (2002) Integration of alien plants into a native flower-pollinator visitation web. Proceedings Royal Society London, 269:2395-2399.

Nurainas N \& Arbain D (2017) A new species and a new record of Zingiberaceae from Sumatra, Indonesia. Taiwania, 62:294-298.

Palupi ER, Adriyani DH, Tjong M \& Krisantini (2019) Flowering and Reproductive Biology of Zingiber spectabile. Pertanika Journal Tropical Agricultural Science, 42:1375-1389.

Parthasarathy VA, Srinivasan V, Nair RR, John ZT, Kumar A \& Prasath D (2012) Ginger: Botany and Horticulture. Horticultural Reviews, 39:273-288.

Peter KV, Ravindran P, Nirmal Babu K \& Divakaran M (2007) Horticulture: vegetables, tubers \& spice crops. Available at: http:/ /nsdl.niscair.res.in/bitstream/123456789/471/1/revised+Breeding. Accessed on: May 27th 2019 
Rivera-Marchand B \& Ackerman JD (2006) Bat pollination breakdown in the Caribbean columnar cactus Pilosocereus royenii. Biotropica, 38:635-642.

Sabu M \& Skinner D (2004) Other economically important Zingiber species. In: Ravindran PN \& Babu KN (Eds.) Gingerthe genus Zingiber. Boca Raton, CRC Press. p.533-545.

Sakai S, Kato M \& Inoue T (1999) Three pollination guilds and variation in floral characteristics of Bornean gingers (Zingiberaceae and Costaceae). American Journal of Botany, 86:646-658.

Sakai S, Kawakita A, Ooi K \& Inoue T (2013) Variation in the strength of association among pollination systems and flora traits: evolutionary changes in the floral traits of Bornean gingers (zingiberaceae). American Journal of Botany, 100:546555 .
Schvinn TA, Miranda AF \& Silva CA (2014) Reproductive biology of Amasonia obovata Gleason (Laminaceae). Acta Amazonica, 44:427-434.

Specht CD, Kress WJ, Stevenson DW \& De Salle R (2001) A molecular phylogeny of Costaceae (Zingiberales). Molecular Phylogenetics and Evolution, 21:333-345.

Thomas GE, Geetha KA, Augustine L, Mamiyil S \& Thomas G (2016) Analyses between reproductive behavior, genetic diversity and Pythium responsiveness in Zingiber spp. reveal an adaptive significance for hemiclonality. Frontiers in Plant Science, 7:19-13.

Thompson AH \& Knight TM (2018) Exotic plant species receive adequate pollinator service despite variable integration into plant-pollinator networks. Oecologia, 187:135-142.

Wu DL \& Larsen K (2000) Zingiberaceae. In: Wu ZY \& Raven PH (Eds.) Flora of China. Beijing, Science Press. p.322-377. 